Wilfrid Laurier University

Scholars Commons @ Laurier

2014

Can I Have Your Attention? Implications of the Research on

Distractions and Multitasking for Reference Librarians

Pauline Dewan
Wilfrid Laurier University, pdewan@wlu.ca

Follow this and additional works at: https://scholars.wlu.ca/lib_pub

Part of the Business Commons, Library and Information Science Commons, and the Psychology Commons

Recommended Citation

Dewan, Pauline. "Can I Have Your Attention? Implications of the Research on Distractions and Multitasking for Reference Librarians." The Reference Librarian 55, no. 2 (2014): 95-117.

This Article is brought to you for free and open access by the Library at Scholars Commons @ Laurier. It has been accepted for inclusion in Library Publications by an authorized administrator of Scholars Commons @ Laurier. For more information, please contact scholarscommons@wlu.ca. 


\title{
Can I Have Your Attention? Implications of the Research on Distractions and Multitasking for Reference Librarians
}

\author{
Pauline Dewan \\ Laurier/Nipissing Liaison Librarian, pdewan@wlu.ca \\ Wilfrid Laurier University Library, Brantford, Ontario, Canada
}

\begin{abstract}
The media have identified the last decade as "the age of distraction." People today find it harder to work on long, sustained tasks because distractions are eroding their attention span, fostering a culture of discontinuity. Fields as diverse as psychology, business, education, human-computer interaction, and communication studies have produced a wealth of studies on interruptions, distractions, and multitasking—research that has important implications for reference librarians. The nature of our jobs invites interruptions by the public, requires familiarity with the latest technology, stimulates curiosity about a broad range of subjects, and demands adeptness at multitasking — all factors which can atomize attention.
\end{abstract}

KEYWORDS distractions, interruptions, multitasking, reference librarians

Chronic distractions have been identified as "the defining condition of the information age," a condition characterized by "continuous partial attention" (Lorinc, 2007, p. 50; Watts et al., 2007, p. 28). As Friedman (2006) observes, "We have gone from the Iron Age to the Industrial Age to the Information Age to the Age of Interruption.” Distractions and interruptions have insidiously crept into our days, eroding our attention span and fostering a culture of discontinuity. Although distractions have always been a part of life, "the mental habit of dividing 
one's attention into many small pieces" has reached "a kind of warp speed" in the last decade (Wallis, 2006). Workplace interruptions are estimated to have doubled from 1995 to 2005 (Spira \& Feintuch, 2005), a trend that has continued. Statistics on them are sobering: we spend an average of 11.5 minutes on a single task before being interrupted; 57 percent of workplace tasks are interrupted; we do not return to an disrupted task 33 percent or more of the time; and 28 percent of a knowledge worker's day is consumed by interruptions (O'Conaill \& Frohlich, 1995; González \& Mark, 2004; Mark, Gonzalez, \& Harris, 2005; Spira \& Feintuch, 2005).

We are so used to interruptions that we have become habituated to a fragmented work style. In a 2013 study, only 9.5 percent of computer users worked exclusively on a single task (Judd). Education research has shown that students multitask 42 percent of class time (Kraushaar \& Novak, 2010). Amazingly, we interrupt ourselves as much as we are interrupted-49.1 percent versus 50.9 percent (González \& Mark, 2004). Fields as diverse as psychology, business, education, human-computer interaction, and communication studies have produced a wealth of studies on interruptions, distractions, and multitasking — research that has important implications for reference librarians. This article will examine not only the culture of distraction that negatively impacts people's working lives, but also multidisciplinary research on the issue, implications for reference librarians, and methods of coping with the challenge.

\section{Distractions and Fragmentation in the Workplace}

Workplace distractions appear in many guises. In the last 40 years, there has been exponential growth in noise levels due to an increase in traffic, industrial plants, and noiseproducing devices - all of which adversely affect workplace efficiency (Zaheeruddin \& Garima, 2006). Irrelevant sounds — and particularly irrelevant speech—disrupt attention and impede cognitive performance (Banbury, Macken, Tremblay, \& Jones, 2001; Jones, Miles, \& Page, 
1990). Not surprisingly, collocated workers experience more interruptions than distributed ones - 62.9 percent versus 49.3 percent (Mark et al., 2005). Open-office designs foster auditory interruptions that interfere with complex tasks, cause concentration impairment, and reduce workplace performance (Roper \& Juneja, 2008). Research has shown that the greater the task complexity, the more detrimental the noise distraction (Zaheeruddin \& Garima, 2006).

In 2004, Gonzalez and Mark concluded that most workplace interruptions are due to faceto-face encounters. Today technological distractions easily surpass human ones as devices become increasingly omnipresent in our lives. Computers appear to have a life of their own, interrupting users with pop-up reminders, email alerts, tweets, chat messages, calendar alerts, software update reminders, and —on Mac computers—bouncing application alerts. Large screens and more powerful computing systems allow for multiple windows and a dizzying array of browser tabs. If our attention is diverted momentarily, it is difficult to find our place again in all our open applications, tabs, and windows. As Doctorow observes (2009),

The biggest impediment to concentration is your computer's ecosystem of interruption technologies: IM, email alerts, RSS alerts, Skype rings, etc. Anything that requires you to wait for a response, even subconsciously, occupies your attention. Anything that leaps up on your screen to announce something new, occupies your attention.

Tablets and smart phones have their own host of distracting reminders. An incoming text, phone call, voicemail alert, task reminder, low battery warning, or update notice announces itself by dinging, vibrating, ringing, playing music, or popping up. And in this mobile world, no matter where a person is, the likelihood of not being interrupted is nonexistent (Spira \& Feintuch, 2005). In a Wall Street Journal piece subtitled, “Here's Why You Won't Finish This Article," Silverman (2012) summarizes the pitfalls of the contemporary workplace: 
The modern workday seems custom-built to destroy individual focus. Open-plan offices and an emphasis on collaborative work leave workers with little insulation from colleagues' chatter. A ceaseless tide of meetings and internal emails means that workers increasingly scramble to get their 'real work' done on the margins, early in the morning or late in the evening. And the tempting lure of social-networking streams and status updates make it easy for workers to interrupt themselves.

The Internet is another "attention black hole" — a "time-sink" waiting to distract us as we bounce between websites and blogs in an "endless click trance" (Doctorow, 2009; Lorinc, 2007). The Internet's seductive nature "allows us to sample almost anything," and "focus on nothing" (Lorinc, 2007, p. 51). The temptation of typing a few words into Google and retrieving millions of hits in mere milliseconds is hard to resist. Surfing the Internet for information often starts in an effort to be well informed but veers off course through a "tyranny of tantalizing choices," ending in a "rabbit hole of Internet distraction" and "a zigzagging pathway that is potentially endless" (Watts et al., 2007, p. 29; Parry, 2013; Hassan, 2012). No matter how many times we are disappointed in our search, we do it again, lulled by the false promise of so many hits.

Never before has it been easier to upload one's thoughts to the world, a situation that, although providing an important voice for people, has resulted in glutting the net to the point of absurdity. It is virtually impossible for knowledge workers to read all the blogs, websites, tweets, and other social media pieces pertinent to their jobs. Reference librarians, who by the very nature of their jobs as well-informed generalists, find it particularly difficult to stay current. Even the traditional ways of disseminating knowledge have far outstripped our ability to keep pace. We read abstracts and snippets and reviews rather than entire articles and books, searching for an 
"intellectual life-raft as the sheer volume of information has become a 'veritable tsunami' washing over," us (Coates, 2009; Horava, 2008).

We need to be aware, as Lorinc (2007, p. 59) points out, "of the futility of the compulsion to inundate ourselves with information in the hope of meaningful processing everything that comes over the digital transom." Added to the challenge of information superabundance is the fact that never before in history have we been faced with so much realtime streaming data and so many live updates on such a variety of devices (Junco \& Cotten, 2012). A whole new emphasis on immediacy requires continual monitoring of instant updatesand thanks to mobile devices and an "always on" mode of living — we have the ability to do so anywhere, anytime (Carr, 2011). Trying to keep pace with this exponentially-increasing sea of information forces us to dip in and out of it, skimming the surface in a disjointed and superficial attempt to stay informed.

More than any other medium, the Internet fragments our attention. Through eye tracking studies, web usability experts have demonstrated that we read only a fraction of the content on a webpage. Nielson's research (2006) reveals an "F" pattern of reading that focuses on the top and left side of a page. Krug (2006, p. 21) observes that most users

glance at each new page, scan some of the text, and click on the first link that catches their interest or vaguely resembles the thing they're looking for. There are usually large parts of the page that they don't even look at.

Online reading is characterized by both skimming pages and jumping from one link to the next. Hyperlinks interrupt linear thought processes and propel us to bounce from one page to another. Reading is further fragmented by page layouts that break content into multiple sections, incorporating features such as sidebars, scrolling text, advertisements, and a variety of 
multimedia content. This "cacophony of stimuli" chips away at our capacity to concentrate and addicts us to "foraging of bits and bytes" (Carr, 2011, p. 91; Lorinc, 2007, p. 51). Because it is impossible to process everything, we develop coping strategies that mimic the web's anti-linear structure. Our reading has given way to skimming; our blogging to tweeting, our letters to emailing and now to texting. At one time, the 160 character limit for a single tweet seemed ridiculously short; now this length suits our harried lifestyles perfectly.

Are the many hours we spend screen reading interfering with our ability to read long, sustained works? Historian, William J. Cronon, argues that today we face what he calls "the Anna Karenina" problem:

Within 20 years ... will students manage to muster the dozens of hours of attention necessary to get through a lengthy novel like Tolstoy's 19th-century classic? If not, what does that mean for works of history that are even harder to read? (Parry, 2013)

In the Pulitzer Prize finalist book The Shallows, Nicholas Carr (2011) argues that because screen reading encourages surface skimming, it discourages deep thinking and sustained reflection-a situation that is particularly alarming since it may be rewiring our brain circuitry. We know that the brain is capable of change and adaptation right until death. Neuroplasticity ensures that "as particular circuits in our brain strengthen through the repetition of a physical or mental activity, they begin to transform that activity into a habit" (Carr, 2011, p. 34).

Constant reading of snippet-length material (of which Google Books is creating a vast, unprecedented online library) not only makes us more impatient with sustained narrative but also creates a vacuum of connection and continuity (Gold, 2002). Greenfield concludes that although the Internet can promote visual intelligence, it does so at the cost of "mindful knowledge acquisition, inductive analysis, critical thinking, imagination, and reflection" $(2009$, p. 71). 
Book-length reading facilitates our cognitive abilities. Carr reminds us that the invention of the printing press and the spread of books led to an expansion of language that spawned further changes:

After's Gutenberg's invention, the bounds of language expanded rapidly as writers, competing for the eyes of ever more sophisticated and demanding readers, strived to express ideas and emotions with superior clarity, elegance, and originality. The vocabulary of the English language, once limited to just a few thousand words, expanded to upwards of a million words as books proliferated. Many of the new words encapsulated abstract concepts that simply hadn't existed before. . . . The ideas that writers could express and readers could interpret became more complex and subtle, as arguments wound their way linearly across many pages of text. As language expanded, consciousness deepened. (2011, p. 75)

Because superficial skimming of material decreases our contact with complex language and ideas, it slowly erodes our capacity to think deeply. Indeed Gold (2002, p. 57) observes, "Brain and language foster each other's development in a symbiotic collusion."

\section{Librarians and Workplace Fragmentation}

Although reference librarians do not have a monopoly on workplace fragmentation, they are particularly vulnerable to it. Interruptions are built into their jobs. Despite the fact that public service work is often the most rewarding part of librarians' duties, it does pose productivity challenges. While waiting for patrons, librarians do not want to become so absorbed in a task that they appear unwelcoming. Yet if few users ask questions, they do not want to waste time.

Reference librarians have access to a vast array of resources and are expected to be knowledgeable about a broad range of fields - a situation that can hamper sustained attention and 
single-minded focus. Trying to keep up with current developments in all fields and staying on top of what Watts and colleagues call the "never-ending and ever-widening stream of incoming data" (2007, p. 29) has become a Herculean task. Our to-do lists are filled with essential blogs, articles, books, listservs, tweets, and RRS feeds that we believe must be read. Ironically "we, whose fundamental role is to acquire, organize, preserve and access information for our user community, are struggling with the problems of managing the information tsunami in our own workspace" (Horava, 2008).

Although working with information is an essential component of all knowledge workers' jobs, it is the very heart of a reference librarian's job. Reference work, according to RUSA (2008), "includes reference transactions and other activities that involve the creation, management, and assessment of information or research resources, tools, and services." Other occupations focus on select segments of the information spectrum. Reference librarians, on the other hand, wade through the entire body of recorded knowledge. In fact, few workers are exposed to more information on a daily basis than librarians. People depend on librarians to navigate information that simply overwhelms them. The job tends to attract people who are curious about information and enjoy learning. Indeed one the core competences for librarianship is "continuing education and lifelong learning" (ALA, 2009). Not surprisingly, many librarians subscribe to email alerts, listservs, rss feeds, and other incoming information services in an effort to keep pace with today's ever-increasing body of knowledge.

Public librarians serve a wide-ranging clientele - from children to senior citizens, and from the less educated to the more. Their patrons are from all walks of life. Broad and varied knowledge is a definite asset in such a role. Readers also expect public librarians (in their role as readers' advisors) to know the books in their collection, and be familiar with authors in all 
genres. Librarians in special libraries may work in a narrower sphere but are required to have expert subject knowledge. According to Hanson's (2011) study of job advertisements, the most cited skill for special librarians is specialized subject knowledge. Academic librarians, as Magi \& Mardeusz (2013) point out, require a "deep and broad knowledge of subjects and terminology" to be effective in their jobs (p. 289). They face the added challenge of unlimited access to a vast array of databases and resources in a broad range of subject areas. The liaison model that is popular in many academic libraries puts added pressure on librarians since it is not uncommon for them to be responsible for at least one subject area outside their area of expertise. How is it possible to be a knowledge librarian in the twenty-first century? Although it is true that librarians need to familiar with the reference tools that locate information, not necessarily, the information itself, it is certainly an asset to well informed in many areas. When constantly overwhelmed with information and distracted by its overabundance, it is difficult to focus or even know where to start. High user- and self-expectations compound the challenge.

Reference librarians do not just provide information for users but empower them by teaching people how to find it for themselves. As RUSA's (2003) professional competencies indicate, the reference librarian "treats the user as a collaborator and partner in the information seeking process." In fact, academic librarians have an explicit mandate to teach information literacy. According to ACRL’s “Information Literacy Competency Standards for Higher Education," the information literate student is able to access, evaluate, and use information effectively (2000). In the age of ubiquitous mobile devices, capturing student attention is a challenge for librarians who teach. According to the latest ECAR report on undergraduates and technology, students own two to three Internet-capable devices (Dahlstrom, Walker, Driuban, \& Morgan, 2013). McCoy (2013) found that students use digital devices for non-class purposes at 
least 10 times a day. Eighty percent of respondents in this study said digital devices caused them to pay less attention in class.

The sheer abundance of journal databases, articles accessed through discovery layers, and link resolvers further distracts students in search of information. Postsecondary students are not the only individuals overloaded with and confused by the plethora of information sources. According to a Pew study, 70 percent of Americans believe that "the amount of news and information available from different sources today is overwhelming" (Purcell, Rainie, Mitchell, Rosenstiel, \& Olmstead, 2010). The job of the modern librarian has increasingly turned from finding information to filtering it, helping to manage the overabundance, and accomplishing this by using the latest tools.

Not surprisingly, librarians feel compelled to stay abreast of the most recent technology, tools, platforms, and devices. Technology is increasingly driving futuristic thinking in libraries, and today's librarians know that, to remain relevant, they must keep pace with technology trends (ACRL Research Planning and Review Committee, 2012; Burns \& Bossaller, 2012). Indeed, according to RUSA's "Professional Competencies for Reference and User Services Librarians" (2003), the reference librarian not only integrates "the latest technology and tools into everyday practice," but also explores emerging technologies and their applications to reference services. Users expect librarians to be able to troubleshoot technology issues. In fact librarians "continue to look more like IT professionals" and "must double as technology gurus" (Mathews \& Pardue, 2009, p. 257; Saunders, 2012, p. 127).

Libraries everywhere have witnessed a steady decline in face-to-face reference transactions as virtual reference gradually replaces in-person consultations. As e-reference (instant messaging, SMS text messaging, voice-over-IP, and email) becomes more popular, as 
virtual instruction expands (video tutorials, podcasts, webinars, screencasts), and as electronic library resources increase in popularity (e-books, streaming video, electronic newspapers, online journals), reference librarians must keep up with newest tools, devices, and platforms. Public librarians, for example, are expected to be familiar with the multitude of e-reading devices that their readers use. Academic librarians must be knowledgeable about technologies such as learning management systems, iClickers, Smart Boards, data tools, and a variety of citation management systems. Trying to master it all, keep abreast of it all, troubleshoot it all, read it all, and, tweet it all is an ongoing challenge.

As the nature of reference work changes, librarians find less time for uninterrupted work. It is common for them to combine shifts at the information desk with chat reference, especially during quieter times of the day. Librarians who provide chat reference are often expected to deliver SMS text messaging and/or voice-over-IP reference at the same time. Burns and Bossaller (2012) examined the impact of information and communication technologies (ICTs) on the work and personal lives of reference librarians. They discovered that librarians typically receive 1,000 emails weekly and that the constant incoming nature of these emails interfered with their ability to focus on work. As one librarian observed, the emails "take up a good portion of the day" (Burns \& Bossaller, 2012, p. 605). To be successful in this service-industry job, it is important to provide timely answers to patrons. But many respondents were concerned that "constant interruptions limit and hinder opportunities to engage deeply with a topic or an issue" (Burns \& Bossaller, 2012, p. 605). Ironically, as the researchers observed, patron emails are the source of librarians' work and, at the same time, an impediment to it. Respondents also indicated that they subscribe to numerous listservs which increase their email load, yet provide much valuable information. As one librarian said, "It's really hard to know what you can tune out and 
not tune out" (Burns \& Bossaller, 2012, p. 605). The study concluded that librarians need time away from digital distractions to work more effectively and maintain work/life balance.

\section{Multitasking in the Workplace}

In response to the sheer volume of information people must deal with and the technological interruptions that characterize their workdays, many individuals have adopted a multitasking work style as a task and information management strategy (Junco \& Cotten, 2012). The term "multitasking" was first introduced to describe a computer's ability to parallel process - to perform more than one task simultaneously (Hassan, 2012). Mark et al. (2005) found that even though people preferred working on one task at a time, in reality they worked on many at once, largely due to multiple external demands on their time. Such demands have increased with a decline in the economy as the same volume of work is often distributed among fewer workers (González \& Mark, 2004). We have become used to responding to an email, an interrupting co-worker, or a text message while working on other tasks. Managing multiple spheres simultaneously is increasingly expected of knowledge workers (Mark et al., 2005). Job descriptions for reference librarians often include the ability to manage a diverse workload as a requirement for the position. To balance the information demands of the job, librarians-like other workers - frequently turn to multitasking as a solution. The ability to multitask is viewed as an enviable trait and proof of a nimble and efficient mind. The constant checking of mobile devices in all possible venues has become epidemic and is considered evidence of productivity.

But would we be more productive if we devoted our undivided attention to one task at a time? Is a steady barrage of interruptions and self-interruptions detrimental to our work? Researchers in multiple fields have studied whether interruptions diminish performance, interfere with learning, decrease productivity, and pose safety risks. Evidence suggests that our 
information processing systems are, for the most part, unable to attend to multiple stimuli. Our brains are ill suited to performing simultaneous tasks because doing so overloads cognitive capacity (Dux, Ivanoff, Asplund, \& Marois, 2006; Koch, Lawo, Fels, \& Vorländer, 2011; Marois \& Ivanoff, 2005; Tombu et al., 2011; Wood et al., 2012). Broadbent's bottleneck theory (1958), Welford's single channel theory (1967), Kahneman's resource theory (1973), and Lang's limited capacity model (2000) all posit a bottleneck at some point in information processing. Only a limited amount of information can be held in working memory before being processed; consequently multitasking "may result in the workflow equivalent of a traffic jam, where projects get backed up behind other projects" (Aral, Brynjolfsson, \& Van Alstyne, 2008, p. 17). Our ability to perform two tasks at the same time is, as Hembrooke and Gay (2003, p. 47) suggest, "at best, limited."

We are, however, more successful at some kinds of multitasking than others. Threaded cognitive theory holds that multitasking "can be represented as the execution of multiple task threads, coordinated by a serial cognitive processor and distributed across multiple processing resources" (Salvucci \& Taatgen, 2008, p. 102). Tasks involving separate modalities (such as auditory and manual) do not compete for the same resources and are processed on different threads. Such tasks are performed with greater likelihood of success than ones belonging to the same modality. Wang et al. (2012) have shown that distributing tasks between the audio and visual modalities results in less performance degradation than undistributed tasks. They recommend that GPS devices rely on audio instructions rather than images since visual resources are not available while driving. Jett and George (2003) also found greater likelihood of successful task completion when tasks are processed on separate channels. Other studies have demonstrated that tasks are more disruptive and result in more bottleneck processing if they are 
too similar and belong to the same modality (Gillie \& Broadbent, 1989; Ruthruff, Van Selst, Johnston, \& Remington, 2006).

When we multitask, we actually rapid-toggle between tasks rather than perform them simultaneously. Threaded cognition theory distinguishes between concurrent and sequential multitasking, the former involving time switches of a second or less, the latter, longer than a second. Concurrent and sequential task toggling can be represented on a temporal continuum; at the one end are switches of milliseconds, on the other end, hours. Concurrent multitasking behavior such as talking while walking is one we perform quite well. Sequential multitasking, however, is what we often refer to when we discuss workplace or classroom multitasking. In general, sequential multitasking poses more interference in task performance (Salvucci \& Taatgen, 2011).

We can toggle between tasks more effectively if there are fewer of them. Research has shown that an increased number of interruptions correlates with lowered performance on decision-making (Nicholson, Nicholson, Parboteeah, \& Valacich, 2009; Speier, Valacich, \& Vessey, 1999). We also perform better if tasks are highly practiced (Dux et al., 2009; Pashler, Harris, \& Nuechterlein, 2008; Ruthruff et al., 2006). Studies indicate that novel or abrupt-onset stimuli are more disruptive than familiar ones, and that it is more difficult to multitask when working on something new or unfamiliar (Jett \& George, 2003; Pashler, Johnston, \& Ruthruff, 2001). Training reduces multitasking costs by increasing the speed of information processing (Dux et al., 2009).

The cost of interruption is also lower if the task if fairly simple. Interruptions at points of higher mental workload are more disruptive than at lower ones (Bailey \& Iqbal, 2008; Mark et al., 2005; Monk, Boehm-Davis, \& Trafton, 2004; Pashler et al., 2008; Speier et al., 1999). When 
working on tasks that require high levels of concentration, we have less working-memory storage and fewer information-processing resources (Gillie \& Broadbent, 1989; Nicholson et al., 2009). Interruption costs are also higher for complex tasks because such tasks cause increased lags in resuming the context of the suspended task (Iqbal \& Bailey, 2005). Since knowledge work demands concentration, librarians are especially vulnerable to the high cost of interrupted tasks. Barrier moments between tasks or subtasks are times of relatively low cognitive load. Consequently, interruptions that take place at task barrier points cause less disruption than those that occur in the midst of a task (Bailey \& Konstan, 2006; Monk, Boehm-Davis, \& Trafton, 2002; Monk et al., 2004). Primary tasks have been shown to resume 69 percent faster when interrupted at workload boundary points (Bailey \& Iqbal, 2008).

People overestimate their ability to deal with distractions, and underestimate the time that these disruptions steal from their day. What begins as a simple break from a task to check an incoming text often leads to a substantial lag in resuming it. Research shows that "users view alerts as an awareness mechanism rather than a trigger to switch tasks, but the alerts often cause them to do otherwise" (Iqbal \& Horvitz, 2007, p. 684). Indeed, most people have little insight into the counterproductive nature of their multitasking:

Even though users feel that they are in control of when they switch tasks due to an alert, they appear to be largely unaware of the amount of time they end up spending on the alerting application, on other tasks they invoke as a result of responding to the alert, and on browsing through other peripheral applications before resuming the suspended task. Even when users respond immediately with the intention of resuming the suspended current task as soon as possible, they often end up taking significantly more time to return than the time to respond. (Iqbal \& Horvitz, 2007, p. 684) 
Similarly, Brasel and Gips (2011, p. 527) found that respondents recalled "their switching behavior at an average of only 12 percent of their actual switching rate." As Wallis and Steptoe (2006) point out, we need to "stop fooling ourselves about our capacities to juggle. We have to resist the 'it will only take a second' impulse to read an e-mail, check a stock price or chat with a colleague in the middle of a demanding assignment." Glenn (2010) observes that when multitaskers' brains have been aroused to execute several tasks, they have an illusory feeling that they are operating at peak performance. Psychology professor, Richard Nass told The Chronicle of Higher Education, "Heavy multitaskers are often extremely confident in their abilities. . But there's evidence that those people are actually worse at multitasking than most people" (Glenn, 2010). Nass and colleagues found that persistent multitaskers do not focus well, are less capable of filtering out irrelevant stimuli than light multitaskers, are less efficient at switching tasks, and are not selective enough about allowing information into working memory (Ophir, Nass, \& Wagner).

Workers believe that they are saving time and being efficient when dealing with multiple tasks at the same time. However, toggling back and forth does not save time and actually sets them back because of switching costs. These costs "result when people must go back and review what they've done before they can resume work on a task. The more complicated the task, the longer it will take ... to become fully engaged" (Time Management, 2005, p. 57). An important indicator of the effects of an interruption is "resumption lag," or "the period of time between completion of the secondary task and the first observed action related to the primary task (Salvucci \& Taatgen, 2011, p. 143). Once people are interrupted or self-interrupt, it takes considerable effort to reacquaint themselves with previous thoughts concerning the primary task. Following an interruption, workers typically visit several applications and do not return to the 
primary task for 25 minutes (Iqbal \& Horvitz, 2007; Mark et al., 2005). Iqbal and Horvitz conclude that "a major problem faced by users attempting to recover applications was restoring the original context of the suspended tasks" (2007, p. 685). "Time and effort with resumption," they speculate, "may involve reacquainting memories about the task, and more generally, refocusing cognitive resources that may have been usurped during the diversion phase" (p. 683). This is one reason why students who multitask while doing homework increase the length of time it takes (Bowman, Levine, Waite, \& Gendron, 2010). Indeed, a large body of research has proven that multitasking or any form of task interruption significantly increases performance time (Aral et al., 2008; Cellier \& Eyrolle, 1992; Fried, 2008; Hembrooke \& Gay, 2003; Iqbal \& Bailey, 2005; Wang et al., 2012). Mobile devices, which facilitate task switching, have been shown to decrease productivity in employees (Nicholson et al., 2009). Ironically, users are wasting time when they believe they are saving it.

Along with decreasing productivity, interrupted tasks lower performance. Research has proven that disrupted activities increase error rates (Altmann \& Trafton, 2002; Bailey \& Konstan, 2006; Cellier \& Eyrolle, 1992; Jones et al., 1990). A number of studies have found that interrupted activities are correlated with task degradation and impaired cognitive performance (Adler \& Benbunan-Fich, 2012; Banbury et al., 2001; Fox, Rosen, \& Crawford, 2009; NavehBenjamin, Craik, Perretta, \& Tonev, 2000; Ophir et al., 2009; Wang et al., 2012). Distractions cause commercial pilot errors (Latorella, 1998), medication prescription errors (Santell, Hicks, McMeekin, \& Cousins, 2003), and higher rates of automobile accidents (Drews, Pasupathi, \& Strayer, 2008; Drews, Yazdani, Godfrey, \& Cooper, 2009). In fact, Strayer and Drews (2004) found that rear-end collisions increase twofold when drivers talk on phones. Drivers using mobile devices and pedestrians listening to headphones while crossing busy intersections are an 
all-too-common sight. Many individuals persist in the belief that, despite the evidence, they are capable of performing simultaneous tasks effectively, even if these activities pose risks. But as Glenn (2010) observes, “beyond a fairly low level of multitasking, everyone’s performance breaks down."

The effects of multitasking on the learning process have been extensively studied. Distractions have always been a part of education but the proliferation of devices and the ubiquity of wireless connectivity offer a steady stream of stimuli that interfere with students' ability to focus (Richtel, 2010b). "The cost of classroom multitasking," as Levy tells The Chronicle of Higher Education, "can be a failure to learn” (Parry, 2013). Multitasking on laptops or mobile devices while listening to lectures or doing homework is negatively related to academic performance (Barak, Lipson, \& Lerman, 2006; Hembrooke \& Gay, 2003; Kraushaar \& Novak, 2010; Kushniryk \& Levine, 2012; Wood et al., 2012). It is also negatively linked to college GPA scores and traditional measures of memory (Hembrooke \& Gay, 2003; Junco \& Cotten, 2012). In fact multitasking impairs not just simple factual learning but also complex applications of it (Sana, Weston, \& Cepeda, 2013). Learning only occurs if we pay attention and think about the lesson-processes that demand concentration. We learn by linking the known to the unknown. According to Lang's limited capacity theory (2009), new knowledge is initially stored in short-term memory. Once it is linked to previous knowledge, it can be stored in longterm memory. The stronger the connections, the stronger the memory, but we have to actively make those connections to learn (Hembrooke \& Gay, 2003; Lang, 2000). And because we have limited information processing capabilities, multitasking during this process can interfere with deeper learning (Junco \& Cotten, 2012). Since our role as information specialists involves lifelong learning, these findings have important implications for our effectiveness as librarians. 
Multitasking is negatively correlated with reading comprehension (Fox et al., 2009). The more time learners spend instant messaging, the greater their difficulty concentrating on academic books (Levine, Waite, \& Bowman, 2007). Reliance on activities such as instant messaging helps create, as Levine and colleagues (2007) point out, “a cognitive style based on quick, superficial multitasking rather than in-depth focus on one task such as reading” (p. 565). Books nurture personal thoughts and ideas but we need time to reflect upon what we read. When we toggle between tasks and face multiple interruptions, we deprive ourselves of this necessary time. "More information can mean less knowledge" when our cognitive processors are overloaded (Carr, 2011, p. 214). Csikszentmihalyi \& Sawyer argue that to gain creative insight, individuals progress through four stages (1995). After the initial research stage, we need idle time to incubate ideas. In this second stage, information is processed by our subconscious minds. The moment of insight emerges after the cessation of conscious activity. In the theory of threaded cognition, such idle time is called "the problem state." When a task is suspended "the task's thread remains active to maintain awareness of the task," allowing background processing of it (Salvucci \& Taatgen, 2011, p. 116). As (Richtel, 2010b) observes, "Downtime is to the brain what sleep is to the body." Multitasking and task interruptions deprive people of the opportunity for critical reflection and creative thinking.

Research has also shown that distractions come at the psychological cost of added stress and frustration (Bailey \& Konstan, 2006; Markel, 2009; Zijlstra, Roe, Leonora, \& Krediet, 1999). Having less time to accomplish projects leads to high levels of stress (Jett \& George, 2003). Psychiatrist, Edward M. Hallowell claims that many workers suffer from a neurological condition called "attention deficit trait" (ADT). Unlike its cousin—attention deficit disorderADT springs solely from the environment and is caused by neurological overload: 
ADT is purely a response to the hyperkinetic environment in which we live. Indeed, modern culture all but requires many of us to develop ADT. Never in history has the human brain been asked to track so many data points. Everywhere, people rely on their cell phones, e-mail, and digital assistants in the race to gather and transmit data, plans, and ideas faster and faster. (2005, p. 57)

According to Hallowell, the number of people suffering from this disorder has increased tenfold over the course of a decade.

\section{Coping with Distractions and Fragmentation in the Workplace}

Computers and mobile devices are increasingly at the core of knowledge workers' everyday tasks (Fogarty et al., 2005, p. 331). As librarians, we cannot escape the distractions that come with technology. "The virtual horse," Anderson (2009) reminds us, "has already left the digital barn. It's too late to just retreat to a quieter time. Our jobs depend on connectivity." No one wants to turn back the clock but we do need to manage our hyper-connected work lives more effectively. Interruptions have become such a fact of life that we seldom resist them (O'Conaill \& Frohlich, 1995). Spira and Feintuch (2005) found that 87.2 percent of employees consider a colleague's interruption acceptable and even two-thirds of them believe that a non-business interruption from a friend is acceptable. Fifty-five percent of employees report answering email immediately or almost immediately; only 35 percent said they do so when convenient. Recognizing the inefficiency of such a work style is the first step in changing it.

Acknowledging that we have an unhealthy dependence on technology, one that is detrimental to our well being, is essential to our mental health (Rosen, 2012). Our dependence on mobile devices borders on addiction. A Time survey found that one in four people check their mobile phones every thirty minutes; one in five, every ten minutes. A third of respondents 
admitted to feeling anxious when unable to check their devices - even for short periods of time (Gibbs, 2012). Framing the issue in terms of mental health may help people recognize its seriousness.

In the rush to stay connected, we have forgotten the value of undivided attention. Multitasking can become a way of life, one that prevents us from living fully in the moment. With mobile devices "we can always be, mentally, digitally, someplace other than where we are" (Gibbs, 2012). For many people, it is increasingly difficult to shut off multitasking tendencies when not multitasking (Richtel, 2010a). Current research has proven that people exhibit less empathy when distracted (Morelli \& Lieberman, 2013). In a profession that prides itself on a personal touch with patrons, multitasking librarians risk compromising this ideal.

One way of avoiding the problems associated with multitasking is adopting the philosophy of "slow living," a movement that started with "slow food" activists in Italy in the late 1980s. Taking time to prepare healthy foods has become a way of life for people disenchanted with the fast-food culture. What began as the slow food movement has expanded to an entire way of living. Slow tourism, slow culture, slow work, città slow, and even slow childrearing have emerged as responses to the hectic pace of modern life (Honoré, 2004; Parkins \& Craig, 2006; Osbaldiston, 2013). Slow living, as Parkins and Craig maintain, "is not a return to the past, the good old days (pre-MacDonalds Arcadia), neither is it a form of laziness, nor a slow-motion version of life" (2006, p. ix). Rather, it is an attempt to disengage from the twentyfirst-century treadmill, change a hectic lifestyle to a more leisurely and holistic one, and consciously engage in more mindful practices (Parkins \& Craig, 2006). One of the key objectives of slow living is to do less but do it better. (Honoré, 2004). A lifestyle dominated by distractions is the enemy of slow living. 
The business literature identifies a number of other ways to effectively cope with workplace distractions. Time management strategies allow us to control distractions that otherwise control us. Recognizing that switching costs are both time-consuming and selfdefeating is an important first step. We cannot avoid all distractions and interruptions but we can identify those tasks that require our undivided attention. Blocking off chunks of time in our calendars to work on them ensures that they do not fall through the multitasking cracks (Time Management, 2005). We need to guard this time assiduously; it is far too easy to let it slip away if we are not proactive about it. Hallowell (2005) suggests setting aside the times of day when we perform at our best to do important work. We must especially protect the time it takes to do complex work. Do not give in to the temptation to check incoming emails, calendar notifications, texts, or other electronic distractions. Recognize that indulging in these activities can be an excuse to delay more demanding tasks. Just because the technology allows anywhere, anytime access does not mean we cannot unplug from the wired world (Markel, 2009). This is easier to do if, instead of setting up incoming alerts, we group distractions together and check them at preestablished times that we control (Jett \& George, 2003). Email that continually trickles in can atomize our days and tempt us to procrastinate (Time Management, 2005). For some people, the impulse to check gadgets and applications is too strong so they manage by leaving their accustomed workspace and relocating to an empty meeting room (Hudson, Christense, Kellogg, \& Erickson, 2002). Others find it easier to work early in the morning or later in the evening when distractions are less frequent (Spira \& Feintuch, 2005). Although hard to do, spending time disconnected is an antidote for the distracted mind (Friedman, 2006). Visualization of the completed task and positive self-talk such as, "I need to control interruptions and keep working" can assist us in our efforts (Markel, 2009, p. 69). 
When we must multitask, we can minimize its disruptive impact by switching tasks during simple rather than complex activities. If we need to toggle during a complex assignment, we should avoid doing so mid-task when cognitive load is highest (Bailey \& Iqbal, 2008; Iqbal \& Bailey, 2005; Monk et al., 2004). We can also minimize switching costs by using artifacts that help us recall the suspended task. Post-it notes, printed email messages with annotations, planners, and special inbox folders all perform the task of the blinking cursor, reorienting us to a suspended task (González \& Mark, 2004; Mark et al., 2005).

We have more control over electronic distractions than auditory ones. A co-worker talking on the phone, listening to a webinar, or working on a noisy copier can be hard to ignore. White noise from a machine such as a fan, earphones connecting us to background music, or even earplugs are options that help some people (Banbury et al., 2001; Sykes, 2011). One of the most difficult distractions to manage is the co-worker who drops by and interrupts. The shift to a more collaborative work environment has opened a "Pandora's box" of distractions for many people (Spira \& Feintuch, 2005, p. 9). Unfortunately some coworkers cannot determine if a question is "important, urgent, both or neither" so they interrupt regardless (Spira, 2005, p. 1). We can either control the timing — by shutting the door — or the length of the disruption by staying at our door for the conversation. Alternatively we can invite the interrupter inside our office, but not encourage the person to sit (Hudson et al., 2002; Jett \& George, 2003). Sometimes it is best to admit right away that we have a deadline to meet.

We have the least control when we are at the desk. Users approach us when they have a need - a situation that, as all reference librarians know, is highly unpredictable. This is one of the few situations where we want to be interrupted. To encourage questions, we need to look interruptible - not so absorbed in a task that our users hesitate to approach. We do not want to 
appear distracted, harried, uninterested in the person in front of us, or unwilling to focus on their request. Activities that are short and demand less sustained attention are best suited for shifts at the desk. Tasks that are complex and require sustained attention are best left for another time.

As information specialists, librarians must take control of their workplace reading. It is no longer possible, if in fact it ever was, to read comprehensively and stay current in everything. It is not even possible to do so in a single field. But this does not mean we should not have a plan or that we should skim rather than read. Recognizing that we cannot process unlimited amounts of material and that we must discard unessential information allows us to better learn, remember, and apply the information that matters (Lorinc, 2007). Acknowledging our limits and prioritizing what is most essential will save us from the feeling that we are continually falling behind. Judicious selectivity of reading material and a plan for scheduled reading time can be effective. Research demonstrates that a fragmented work style diminishes productivity, erodes performance, interferes with learning, impedes creative and critical thinking, and increases stress levels. Yet some degree of fragmentation is built into our workday and is simply unavoidable. Even though phrases such as "train of thought" and "undivided attention" are becoming antiquated in our culture (Lorinc, 2007, p. 51), we need not accept a disruptive and disjointed work style as inevitable and defeating. We do have more control over the timing, frequency, and management of disruptions than we might initially believe. The key is to recognize the detrimental effects of accumulated interruptions and self-interruptions over the course of time, and to value and protect the opportunities we have to single-mindedly attend to tasks.

\section{References}

Adler, R. F., \& Benbunan-Fich, R. (2012). Juggling on a high wire: Multitasking effects on performance. International Journal of Human-Computer Studies, 70(2), 156-168. doi:10.1016/j.ijhcs.2011.10.003 
ACRL (The Association of College and Research Libraries). (2000). Information literacy competency standards for higher education, 1-17. Retrieved from http://www.ala.org/acrl/sites/ala.org.acrl/files/content/standards/standards.pdf

ACRL Research Planning and Review Committee. (2012). 2012 top ten trends in academic libraries: A review of the trends and issues affecting academic libraries in higher education. College \& Research Libraries News, 73(6), 311-320. Retrieved from http://crln.acrl.org/content/73/6/311.full.pdf+html

ALA (American Library Association). (2009). ALA's core competences of librarianship. Retrieved from http://www.ala.org/educationcareers/careers/corecomp/corecompetences

Altmann, E. M., \& Trafton, J. G. (2002). Memory for goals: An activation-based model. Cognitive Science, 26(1), 39-83. doi:10.1207/s15516709cog2601_2

Anderson, S. (2009). In defense of distraction. New York Magazine. Retrieved from http://nymag.com/news/features/56793/

Aral, S., Brynjolfsson, E., \& Van Alstyne, M. W. (2008). What makes information workers productive. MIT Sloan Management Reviw, 49(2).

Bailey, B. P., \& Iqbal, S. T. (2008). Understanding changes in mental workload during execution of goal-directed tasks and its application for interruption management. ACM Transactions on Computer-Human Interaction, 14(4), 1-28. doi:10.1145/1314683.1314689

Bailey, B. P., \& Konstan, J. A. (2006). On the need for attention-aware systems: Measuring effects of interruption on task performance, error rate, and affective state. Computers in Human Behavior, 22(4), 685-708. doi:10.1016/j.chb.2005.12.009

Banbury, S. P., Macken, W. J., Tremblay, S., \& Jones, D. M. (2001). Auditory distraction and short-term memory: Phenomena and practical implications. Human Factors, 43(1), 12-29. Retrieved from http://www.ncbi.nlm.nih.gov/pubmed/11474757

Barak, M., Lipson, A., \& Lerman, S. (2006). Wireless laptops as means for promoting active learning in large lecture halls. Journal of Research on Technology in Education, 38(3), 245264.

Bowman, L. L., Levine, L. E., Waite, B. M., \& Gendron, M. (2010). Can students really multitask? An experimental study of instant messaging while reading. Computers \& Education, 54(4), 927-931. doi:10.1016/j.compedu.2009.09.024

Brasel, S. A., \& Gips, J. (2011). Media multitasking behavior: Concurrent television and computer usage. Cyberpsychology, Behavior and Social Networking, 14(9), 527-534. doi:10.1089/cyber.2010.0350

Broadbent, D. E. (1958). Perception and communication. Elmsford, NY: Pergamon Press. 
Burns, C. S., \& Bossaller, J. (2012). Communication overload: A phenomenological inquiry into academic reference librarianship. Journal of Documentation, 68(5), 597-617. doi:10.1108/00220411211255996

Carr, N. G. (2011). The shallows: What the Internet is doing to our brains. New York: W. W. Norton.

Cellier, J., \& Eyrolle, H. (1992). Interference between switched tasks. Ergonomics, 35(1), 25-36. doi:10.1080/00140139208967795

Coates, K. (2009, March 23). Knowledge overload. Inside Higher Ed. Retrieved from http://www.insidehighered.com/views/2009/03/23/coates

Csikszentmihalyi, M., \& Sawyer, K. (1995). Creative insight: The social dimension of a solitary movement. In R. J. Stern-berg \& J. E. Davidson (Eds.), The nature of insight (pp. 329-363). Cambridge, MA: MIT Press.

Dahlstrom, E., Walker, J. D., Dziuban, C., \& Morgan, G. (2013). ECAR study of undergraduate students and information technology, 2013 (pp. 1-49). Louisville, CO. Retrieved from https://net.educause.edu/ir/library/pdf/ERS1302/ERS1302.pdf

Doctorow, C. (2009, January). Writing in the age of distraction. Locus Magazine. Retrieved from http://www.locusmag.com/Features/2009/01/cory-doctorow-writing-in-age-of.html

Drews, F. A., Pasupathi, M., \& Strayer, D. L. (2008). Passenger and cell phone conversations in simulated driving. Journal of Experimental Psychology. Applied, 14(4), 392-400. doi:10.1037/a0013119

Drews, F. A., Yazdani, H., Godfrey, C. N., \& Cooper, J. M. (2009). Text messaging during simulated driving. Human Factors, 51(5), 762-770. doi:10.1177/0018720809353319.

Dux, P. E., Ivanoff, J., Asplund, C. L., \& Marois, R. (2006). Isolation of a central bottleneck of information processing with time-resolved fMRI. Neuron, 52(6), 1109-1120. doi:10.1016/j.neuron.2006.11.009

Dux, P. E., Tombu, M. N., Harrison, S., Rogers, B. P., Tong, F., \& Marois, R. (2009). Training improves multitasking performance by increasing the speed of information processing in human prefrontal cortex. Neuron, 63(1), 127-138. doi:10.1016/j.neuron.2009.06.005

Fogarty, J., Ko, A. J., Aung, H. H., Golden, E., Tang, K. P., \& Hudson, S. E. (2005). Examining task engagement in sensor-based statistical models of human interruptibility. CHI, 331-340. doi:10.1145/1054972.1055018

Fox, A. B., Rosen, J., \& Crawford, M. (2009). Distractions, distractions: Does instant messaging affect college students' performance on a concurrent reading comprehension task? Cyberpsychology \& Behavior, 12(1), 51-53. doi:10.1089/cpb.2008.0107 
Fried, C. B. (2008). In-class laptop use and its effects on student learning. Computers \& Education, 50(3), 906-914. doi:10.1016/j.compedu.2006.09.006

Friedman, T. L. (2006, July 5). The age of interruption. The New York Times. Retrieved from www.nytimes.com/2006/07/05/opinion/05friedman.html

Gibbs, N. (2012, August 16). Your life is fully mobile: We walk, talk and sleep with our phones. But are we more - or less-connected? Time. Retrieved from http://techland.time.com/2012/08/16/your-life-is-fully-mobile/

Gillie, T., \& Broadbent, D. (1989). What makes interruptions disruptive? A study of length, similarity, and complexity. Psychological Research, 50(4), 243-250. doi:10.1007/BF00309260

Glenn, D. (2010, February 28). Divided attention: In an age of classroom multitasking, scholars probe the nature of learning and memory. Chronicle of Higher Education. Retrieved from http://chronicle.com/article/Scholars-Turn-Their-Attention/63746/

González, V. M., \& Mark, G. (2004). "Constant, constant, multi-tasking craziness": Managing multiple working spheres. CHI, 6(1), 113-120.

Greenfield, P. M. (2009). Technology and informal education: What is taught, what is learned. Science, 323(2), 69-71.

Hallowell, E. M. (2005). Overloaded circuits: Why smart people underperform. Harvard Business Review, 83(1), 55-62.

Hansen, K. (2011). Education, training, and recruitment of special collections librarians: An analysis of job advertisements. RBM: A Journal of Rare Books, Manuscripts, and Cultural heritage, 12(2), 110-133.

Hassan, R. (2012). The chronic distraction of everyday life. In The age of distraction: Reading, writing, and politics in a high-speed networked economy (pp. 107-137). New Brunswick, NJ: Transaction.

Hembrooke, H., \& Gay, G. (2003). The laptop and the lecture: The effects of multitasking in learning environments. Journal of Computing in Higher Education, 15(1), 46-64.

Horava, T. (2008). Navigating our days in a culture of distraction. Partnership: The Canadian Journal of Library and Information Practice and Research, 3(2). Retrieved from https://journal.lib.uoguelph.ca/index.php/perj/article/viewFile/546/1329

Honoré, C. (2004). In praise of slow: How a worldwide movement is challenging the cult of speed. Toronto, ON: Vintage Canada. 
Hudson, J. M., Christense, J., Kellogg, W. A., \& Erickson, T. (2002). "I'd be overwhelmed, but it's just one more thing to do": Availability and interruption in research management. $\mathrm{CHI}$, 97-104.

Iqbal, S. T., \& Bailey, B. P. (2005). Investigating the effectiveness of mental workload as a predictor of opportune moments for interruption. CHI, 1489-1492. doi:10.1145/1056808.1056948

Iqbal, S. T., \& Horvitz, E. (2007). Disruption and recovery of computing tasks: Field study, analysis , and directions. $\mathrm{CHI}, 677-686$.

Jett, Q. R., \& George, J. M. (2003). Work interrupted: A closer look at the role of interruptions in organizational life. The Academy of Management Review, 28(3), 494-507.

Jones, D. M., Miles, C., \& Page, J. (1990). Disruption of proofreading by irrelevant speech: effects of attention, arousal or memory? Applied Cognitive Psychology, 4(2), 89-108.

Joseph Gold. (2002). The story species: Our life-literature connection. Toronto, ON: Fitzhenry \& Whiteside.

Judd, T. (2013). Making sense of multitasking: Key behaviours. Computers \& Education, 63, 358-367. doi:10.1016/j.compedu.2012.12.017

Junco, R., \& Cotten, S. R. (2012). No A 4 U: The relationship between multitasking and academic performance. Computers \& Education, 59(2), 505-514. doi:10.1016/j.compedu.2011.12.023

Kahneman, D. (1973). Attention and effort. Englewood Cliffs, NJ: Prentice-Hall.

Koch, I., Lawo, V., Fels, J., \& Vorländer, M. (2011). Switching in the cocktail party: Exploring intentional control of auditory selective attention. Journal of Experimental Psychology. Human Perception and Performance, 37(4), 1140-1147. doi:10.1037/a0022189

Kraushaar, J. M., \& Novak, D. C. (2010). Examining the affects of student multitasking with laptops during the lecture. Journal of Information Systems Education, 21(2), 241-252.

Krug, S. (2006). Don't make me think: A common sense approach to web usability (2nd ed.). Berkeley, CA: New Riders.

Kushniryk, A., \& Levine, K. J. (2012). Impact of multitasking on listening effectiveness in the learning environment. The Canadian Journal for the Scholarship of Teaching and Learning, 3(2), 1-11. doi:10.5206/cjsotl-rcacea.2012.2.7

Lang, A. (2000). The limited capacity model of mediated message processing. Journal of Communication, 50(1), 46-70. doi:10.1093/joc/50.1.46 
Latorella, K. A. (1998). Effects of modality on interrupted flight deck performance: implications for data link. Proceedings of the Human Factors and Ergonomics Society 42nd Annual Meeting, 87-91. Retrieved from http://interruptions.net/literature/Latorella-HFES98.pdf

Levine, L. E., Waite, B. M., \& Bowman, L. L. (2007). Electronic media use, reading, and academic distractibility in college youth. Cyberpsychology \& Behavior, 10(4), 560-566. doi:10.1089/cpb.2007.9990

Lorinc, J. (2007). Driven to distraction: How our multi-channel, multi-tasking society is making it harder for us to think. The Walrus, 4(5), 50-57. Retrieved from http://www.ncbi.nlm.nih.gov/pubmed/23257928

Magi, T. J., \& Mardeusz, P. E. (2013). What students need from reference librarians. College \& Research Libraries News, 74(6), 288-291. Retrieved from http://crln.acrl.org/content/74/6/288.full.pdf+html

Mark, G., Gonzalez, V. M., \& Harris, J. (2005). No task left behind? Examining the nature of fragmented work. $C H I, 321-330$.

Markel, G. (2009). How learning professionals can keep technology distractions at bay. $T+D$, 63(9), 68-69.

Marois, R., \& Ivanoff, J. (2005). Capacity limits of information processing in the brain. Trends in Cognitive Sciences, 9(6), 296-305. doi:10.1016/j.tics.2005.04.010

Mathews, J. M., \& Pardue, H. (2009). The presence of IT skill sets in librarian position announcements. College \& Research Libraries, 70(3), 250-257. Retrieved from http://crl.acrl.org/content/70/3/250.full.pdf+html

McCoy, B. R. (2013). Digital distractions in the classroom: Student classroom use of digital devices for non-class related purposes. The Journal of Media Education, 4(4), 5-12.

Monk, C. A., Boehm-Davis, D. A., \& Trafton, J. G. (2002). The attentional costs of interrupting task performance at various stages. Proceedings of the Human Factors and Ergonomics Society 46th Annual Meeting, 46(22), 1824-1828. doi:10.1177/154193120204602210

Monk, C. A., Boehm-Davis, D. A., \& Trafton, J. G. (2004). Recovering from interruptions: Implications for driver distraction research. Human Factors, 46(4), 650-663. Retrieved from http://www.ncbi.nlm.nih.gov/pubmed/15709327

Morelli, S. A, \& Lieberman, M. D. (2013). The role of automaticity and attention in neural processes underlying empathy for happiness, sadness, and anxiety. Frontiers in Human Neuroscience, 7(May), 1-15. doi:10.3389/fnhum.2013.00160

Naveh-Benjamin, M., Craik, F. I. M., Perretta, J. G., \& Tonev, S. T. (2000). The effects of divided attention on encoding and retrieval processes: The resiliency of retrieval processes. 
The Quarterly Journal of Experimental Psychology. A, Human Experimental Psychology, 53(3), 609-625. doi:10.1080/713755914

Nicholson, D. B., Nicholson, J. A., Parboteeah, D. V., \& Valacich, J. S. (2009). Investigating the effects of distractions and task complexity on knowledge worker productivity in the context of mobile computing environments. Journal of Organizational and End User Computing, 21(4), 1-20. doi:10.4018/joeuc.2009062601

Nielsen, J. (2006). F-Shaped pattern for reading web content. Retrieved from http://www.nngroup.com/articles/f-shaped-pattern-reading-web-content/

O'Conaill, B., \& Frohlich, D. (1995). Timespace in the workplace: Dealing with interruptions. CHI, 262-263.

Ophir, E., Nass, C., \& Wagner, A. D. (2009). Cognitive control in media multitaskers. Proceedings of the National Academy of Sciences of the United States of America, 106(37), 15583-15587. doi:10.1073/pnas.0903620106

Osbaldiston, N. (Ed.). (2013). Culture of the slow: Social deceleration in an accelerated world. New York: Palgrave Macmillan.

Parkins, W., \& Craig, G. (2006). Slow living. Oxford: Berg.

Parry, M. (2013, March 24). You're distracted. The Chronicle of Higher Education. Retrieved from http://chronicle.com/article/Youre-Distracted-This/138079/

Pashler, H., Harris, C. R., \& Nuechterlein, K. H. (2008). Does the central bottleneck encompass voluntary selection of hedonically based choices? Experimental Psychology, 55(5), 313321. doi:10.1027/1618-3169.55.5.313

Pashler, H., Johnston, J. C., \& Ruthruff, E. (2001). Attention and performance. Annual Review of Psychology, 52, 629-651. doi:10.1146/annurev.psych.52.1.629

Purcell, K., Rainie, L., Mitchell, A, Rosenstiel, T., \& Olmstead, K. (2010). Understanding the participatory news consumer. PEW Report. Retrieved from http://www.pewinternet.org/Reports/2010/Online-News.aspx

RUSA (Reference and User Services Association). (2008). Definitions of reference. Retrieved from http://www.ala.org/rusa/resources/guidelines/definitionsreference

RUSA (Reference and User Services Association). (2003). Professional competencies for reference and user services librarians. Retrieved from http://www.ala.org/rusa/resources/guidelines/professional 
Richtel, M. (2010a, June 6). Attached to technology and paying a price. The New York Times. Retrieved from http://www.nytimes.com/2010/06/07/technology/07brain.html?pagewanted=all\&_r=0

Richtel, M. (2010b, November 21). Growing up digital, wired for distraction. The New York Times. Retrieved from http://www.nytimes.com/2010/11/21/technology/21brain.html?_r=0

Roper, K. O., \& Juneja, P. (2008). Distractions in the workplace revisited. Journal of Facilities Management, 6(2), 91-109. doi:10.1108/14725960810872622

Rosen, L. (2012). iDisorder: Understanding our obsession with technology and overcoming its hold on us. New York: Palgrave Macmillan.

Ruthruff, E., Van Selst, M., Johnston, J. C., \& Remington, R. (2006). How does practice reduce dual-task interference: Integration, automatization, or just stage-shortening? Psychological Research, 70(2), 125-142. doi:10.1007/s00426-004-0192-7

Salvucci, D. D., \& Taatgen, N. A. (2008). Threaded cognition: An integrated theory of concurrent multitasking. Psychological Review, 115(1), 101-130. doi:10.1037/0033295X.115.1.101

Salvucci, D. D., \& Taatgen, N. A. (2011). The multitasking mind. Oxford: Oxford University Press.

Sana, F., Weston, T., \& Cepeda, N. J. (2013). Laptop multitasking hinders classroom learning for both users and nearby peers. Computers \& Education, 62, 24-31. doi:10.1016/j.compedu.2012.10.003

Santell, J. P., Hicks, R. W., McMeekin, J., \& Cousins, D. D. (2003). Medication errors: Experience of the United States pharmacopeia (USP) MEDMARX reporting system. The Journal of Clinical Pharmacology, 43(7), 760-767. doi:10.1177/0091270003254831

Saunders, L. (2012). The reality of reference: Responsibilities and competencies for current reference librarians. Public Services Quarterly, 8(2), 114-135. doi:10.1080/15228959.2012.662074

Silverman, R. E. (2012, December 12). Workplace distractions: Here's why you won't finish this article. Wall Street Journal. Retrieved from http://online.wsj.com/article/SB10001424127887324339204578173252223022388.html

Speier, C., Valacich, J. S., \& Vessey, I. (1999). The influence of task interruption on individual decision making: An information overload perspective. Decision Sciences, 30(2), 337-360. doi:10.1111/j.1540-5915.1999.tb01613.x

Spira, J. B. (2005). The high cost of interruptions. KM World: Content, Document and Knowledge Management, 14(8), 1, 32. 
Spira, J. B., \& Feintuch, J. B. (2005). The cost of not paying attention: How interruptions impact knowledge worker productivity. Retrieved from http://www.basex.com/web/tbghome.nsf/23e5e39594c064ee852564ae004fa010/ea4eae828b d411be8525742f0006cde3/\$file/costofnotpayingattention.basexreport.pdf

Strayer, D. L., \& Drews, F. A. (2004). Profiles in driver distraction: Effects of cell phone conversations on younger and older drivers. Human Factors, 46(4), 640-649. Retrieved from http://www.ncbi.nlm.nih.gov/pubmed/15709326

Sykes, E. R. (2011). Interruptions in the workplace: A case study to reduce their effects. International Journal of Information Management, 31(4), 385-394. doi:10.1016/j.ijinfomgt.2010.10.010

Time management: Increase your personal productivity and effectiveness. (2005). Boston, MA: Harvard Business School Press.

Tombu, M. N., Asplund, C. L., Dux, P. E., Godwin, D., Martin, J. W., \& Marois, R. (2011). A Unified attentional bottleneck in the human brain. Proceedings of the National Academy of Sciences of the United States of America, 108(33), 13426-13431. doi:10.1073/pnas.1103583108

Wallis, C. (2006). The Multitasking Generation. Time, 167(13), 34-41.

Wallis, C., \& Steptoe, S. (2006). Staying Sharp: Help! I've Lost My Focus. Time, 167(3), 42-48.

Wang, Z., David, P., Srivastava, J., Powers, S., Brady, C., D’Angelo, J., \& Moreland, J. (2012). Behavioral performance and visual attention in communication multitasking: A comparison between instant messaging and online voice chat. Computers in Human Behavior, 28(3), 968-975. doi:10.1016/j.chb.2011.12.018

Watts, D. J., Reinhardt, E., Magic, B., \& Potter, H. (2007). The HBR: Breakthrough ideas for 2007. Harvard Business Review, 85(2), 20-54.

Welford, A. T. (1967). Single-channel operation in the brain. Acta Psychologica, 27, 5-22.

Wood, E., Zivcakova, L., Gentile, P., Archer, K., De Pasquale, D., \& Nosko, A. (2012). Examining the impact of off-task multi-tasking with technology on real-time classroom learning. Computers \& Education, 58(1), 365-374. doi:10.1016/j.compedu.2011.08.029

Zaheeruddin, \& Garima. (2006). A neuro-fuzzy approach for prediction of human work efficiency in noisy environment. Applied Soft Computing, 6(3), 283-294. doi:10.1016/j.asoc.2005.02.001

Zijlstra, F. R. H., Roe, R. A., Leonora, A. B., \& Krediet, I. (1999). Temporal factors in mental work: Effects of interrupted activities. Journal of Occupational Psychology, 72(2), 163185. 
